\title{
Biodiesel in Holy Quran: Among The Review of The Arabic Lexicography and Modern Science
}

Saipolbarin Ramli

Sumaiya Zainal Abidin Murad

Ahmad Fikri Hj Husin

Sultan Idris Education University, University of Malaysia Pahang, University of Malaya

saipolbarin@fbk.upsi.edu.my

\author{
DOI:10.5901/mjss.2014.v5n19p336
}

\begin{abstract}
The Holy Qur'an is a miracle revealed to Prophet Muhammad, Sallallahu Alayhi Wa Salam, that not only discusses elements on beliefs but at the same time, it is compact with some absolutely amazing scientific facts. There are many verses that discuss the description of the scientific facts in the holy Quran. Among the scientific facts found in the holy Quran is the verse that deals with the concept of energy sources such as biodiesel which is found in Yaseen verse 80. However, the interpretation of this verse according to academicians of the past has been from a different perspective. Findings in the biodiesel field by modern scientists have opened a new chapter in the interpretation related to the biodiesel concept found in the holy Qur'an. This study will analyze the opinion of the Arab-Islamic scholars in the interpretation of this verse from the perspective of Islamic code and Arabic lexicography. Furthermore, this discussion will be conducted to examine the relationship of this verse with the concept of biodiesel from the perspective of modern science. The results of the experiments that have been conducted showing that the amount of energy that results from the reaction of plants, solvents and catalysts to produce biodiesel which is one of the potential of alternative energy sources to replace conventional fuels. The formation of the chemical structure of biodiesel produced from the breakdown of triglyceride structure ( i.e oil from green plants) that reacts with hydroxide ions and produce three molecules of fatty acid methyl esters FAME (i.e biodiesel) and one molecule of glycerol. It shows that green elements found in plants is an energy element. It is hoped that this study will open up new perspectives on the interpretation of the verse that relates to the concept of biodiesel in holy Quran based on scientific facts. Indirectly, it also proves that the holy Quran is the revelation of God and not the invention of Prophet Muhammad.
\end{abstract}

Keywords: Biodiesel, Holy Quran, Modern Science, Code Interpretation, Arabic Lexicography

\section{Introduction}

The holy Quran is a revelation of Allah serves as guidance to mankind. The holy Quran itself has great universal value covering all aspects of knowledge and not only focusing to specific areas such as doctrine, jurisprudence, tajweed, etc, but its use including several other fields such as medical science, astronomy, psychology, technology and so on. (Zamri Rajab, Kaseh Abu Bakar, 2011:84). The development and progress in science and technology indirectly affect the understanding of the texts of the Quran like the understanding of the concept of biodiesel in the holy Quran. Allah clearly mentions about the concept of this biodiesel in surah Yaseen on the verse 80, the words of Allah:

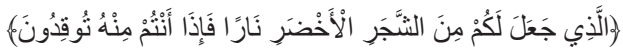

Meaning: (Allah) who has made the wet green trees (energy source) for you (to use), then you kindle fire from the trees. (36:80).

Understanding of the interpretation of this verse among ancient commentators are from a different angle. With the advancement in science and technology, an understanding of the different perceptions of the concept of this verse can be explored and indirectly it is a recognition of the miracle of the content of holy Quran. To get a correct picture of the

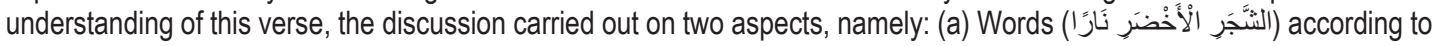
the Arabic lexicography and code interpretation, (b) The concept of biodiesel according to scientists. 
Words (الثَََّرِ الأَخْضَرِ نَارًا) According to the Arabic Lexicography and Code Interpretation

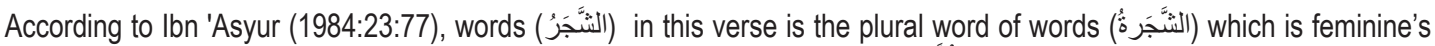

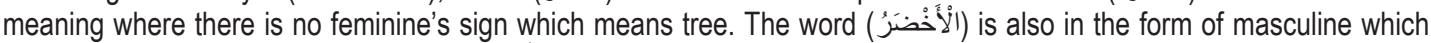

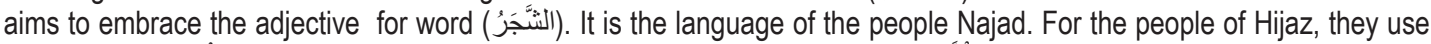

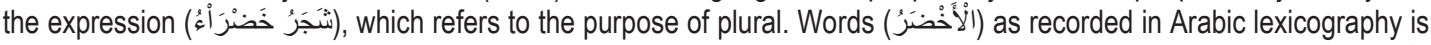
referring to the purpose of a known color and is widely available in the color of the plants. The color is green. Words (نَارَ),

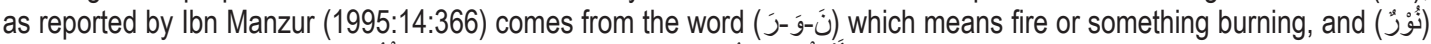

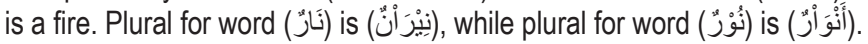

Al-Qurtubiy (2006:17:491) explains that this verse is a reminder of Allah to the people of the concept of faith and the power of God to turn things. Normally people see dry wood used as fuel, but God has lit a fire of green plants are still wet. It is a truth from Allah to the people who doubt the power of God. Ibn 'Attiyat (2007:7:267) stated that this verse was revealed in response to al-'As Ibn al-Sahamiy Wa'il's ridicule of mocking Allah in reviving the shattered bones. Allah revealed this verse that conveys the message that nothing seems impossible for Allah. Perhaps in the eyes of man it is a strange and impossible, but not the eyes of almighty Allah. There are two thoughts of the commentators relating to the interpretation of

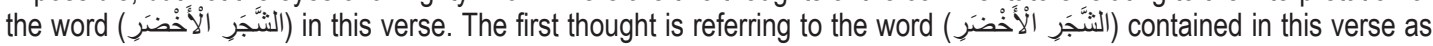
metaphor. The use of metaphor in this verse is a form of language style in holy Quran. The true meaning of this verse is that the trees are dead and dried are used as fuel. According to Ibn Kathir (1999:3:172), the interpretation of this verse means Allah turn wet and green trees from water. Upon reaching a certain extent, these trees will die and dry. The trees are dead and dried will be used as fuel to produce heat. This verse is similar to the context of the verse in surah al-Nisa' verse 2 , the word of almighty Allah:

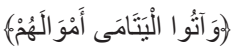

Meaning: "And give to the orphans their property" (4:2)

Allah uses the word 'orphan' in the text, while the orphan's property should be handed to them is when they have reached the age of puberty. When a young orphan has grown and come of age and be able to manage themselves, so in terms of the rule they are no longer orphanage. Al-'Alaqat al-Majaz which is found in this verse mentioned about things happened in the past, but what it means is things that happen now. This verse means to give the property of orphans who have reached the age of puberty to them. Same condition applies to the paragraph above. The meaning of the verse is that green plants have died and burnt dry. Referred to in this verse is that the plants have died and dried, but what being mentioned was referred to the plants is still green and wet. In the discussion of Arabic rhetoric term, the condition is known as al- 'Alaqat al-Majaz (عَلَى اعتنتَبَارِ مَاْ كَانَ) which is mentioned that past thing, but the actual meaning is things that still going

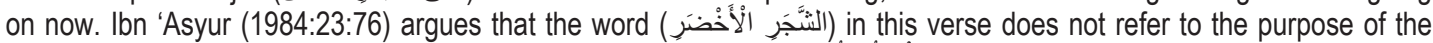

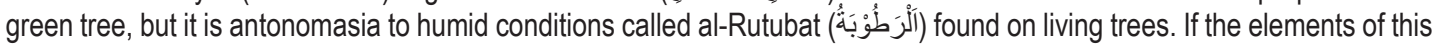
moisture is lost, automatically the trees change color and will dry out and die.

Meanwhile, al-Maraghiy (1946:23:38) explains this verse means Allah has turned the trees of water resources. These trees will grow and turn green. Eventually the trees will die and dry. The trees that have dried are to be used as fuel. Allah has power to restore the moisture contained in the seed after it is mixed with water. Furthermore, Allah also has the power to remove moisture until it can be used as fuel. In this chapter, Allah preach about His authority has created a seven-layered sky with planets on it, created seven earths full of inhabitants as in verse 81 , and revive the bones that have been destroyed and decomposed as in verse 79 . All three of these creations are something that are beyond the wit of human thought, but it is not impossible for almighty Allah.

Al-Zarkasyiy (1984:3:457) discuss this description based on a rhetorical term in the holy Qur'an from the point of the beauty

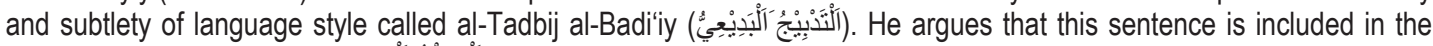

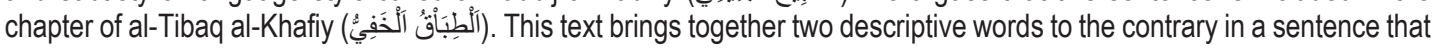
is green found on plants and red which is found on fire. Both of these colors are opposite each other in nature. The green color in plants is characteristically cold and wet, while the red color on the fire was hot and dry in nature. The life cycle of green plants, ranging from the nature of water droplets cool and wet mixed with soil and seeds. This attribute is inconsistent with the nature of fire is hot and dry. By the logic of the human mind, these two elements are irreconcilable. Nevertheless, Allah s.w.t has power to bring both elements at the same time which God brought together the two elements on the tree trunk. 


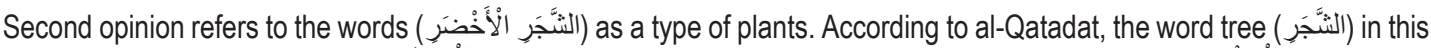

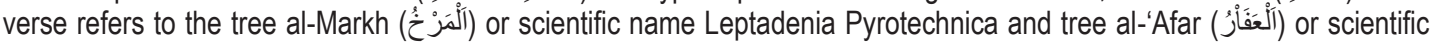
name Arbouse that grows in the Hijaz area. The Arabs use sticks from the trees to produce fire. The friction of the two trees will produce fuel into fuel for their use. Meanwhile, according to Ibn Hayyan al-Andalusiy (1993:6:333) this verse shows the power of God to create something that is impossible according to human logic. This is because of the cold water used to extinguish the fire, but in this verse Allah makes green and wet plants to produce fire. Both of these elements (water and fire) is the ambivalence that are incorporated in this verse to show the power of almighty Allah. Al-Baidawiy (1998:16:199) explains that the green tree meant in this verse is the al-Markh and al-'Afar. Both of these trees will produce heat when both wood from the trees rubbed together with water. The use of al-Tanween in the word (نَارً) show miracle thing. Miracle thing in this verse is that when a fire resulting from green plants. In Arab society, the description of green plants can produce fuel is a known phenomenon. It can be seen with the use of these descriptors in their proverbs and poetry. In the book Jamharat al-Amthal by Abu Hilal al-'Askariy (1988:2:81), there is a proverb that reflects the description of the two trees, which are:

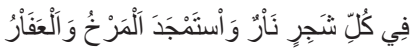

Meaning: "Each tree is fire, especially trees of al-Markh and al-'Afar".

Lecture: "Each person has their own advantage, and in a crowd is definitely one of the best there is".

Another proverb which says:

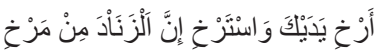

Meaning: "Lighten the hands of beggars, even if the fire is lit from Markh tree".

Lecture: "Do not asking from others, even from the most generous, it is sufficient enough with igniting a small

fire from Markh tree that can indeed produce a big fire".

In the process of producing fire from the two trees, the tree al-'Afar will be in the top position while al-Markh tree sits at the bottom position. Both of these trees will rub together. The setting position of both these trees has been noted among the Arabs until they use this description in their poems as found in Diwan al-Kumait bin Zaid al-Asadiy (2000:74):

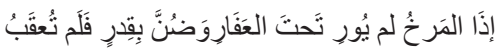

Meaning: "If al-Markh tree does not produce fire under the al-Afar tree, it is enough with what you have and

do not complain".

Lecture: "A person who has already noble and commendable needs no praise and denigration of others".

'Abd al-Mun'im al-Fahim Hadiy (1996:114) argues that there are verses in the holy Qur'an is constantly evolving in terms of interpretation from time to time on the progress of human civilization. This interpretation of this verse will evolve in line with the level of progress made by man. The interpretation of this verse from the interpretation which refers to al-Markh trees and al-'Afar. Next it refers to the process of producing charcoal from wood trees that are still wet and for some time been a source of fuel that is vital to human civilization. Final interpretation of this verse is referring to the petroleum produced from the decomposition of green plants and animals that occur in hundreds of years. Petroleum has become the most important fuel in the production of energy to humans. All interpretations associated with this sentence accepted and have a direct connection with the verse 80 of Surah Yaseen.

\section{The Concept of Biodiesel According to Scientists}

Biodiesel can be produced by transesterification of any triglyceride feedstock, which includes any oil-bearing crops, animal fats and algal lipids. However, most current research is focusing considerably on the production of biodiesel from vegetable oil (Balat, 2011; Hoekman et al., 2012). The use of vegetable oils as an alternative fuel has been around for 100 years, ever since the invention of the compression ignition engine by Rudolph Diesel using peanut oil (Shay, 1993). Different countries use different types of vegetable oils, depending upon the climate and soil conditions (Sharma et al., 2008). For example, soybean oil is commonly used in the United States, rapeseed and sunflower oil are used in many European countries, coconut oil is used in the Philippines and palm oils are used in Malaysia for biodiesel production (Ghadge and Raheman, 2005; Demirbas, 2006; Meher et al.,2006 a; Sarin et al.,2007). These four crops, soybean, rapeseed, palm and sunflower noticeably dominate the feedstock sources used for worldwide biodiesel production. However, there are no 
limitations for employing other types of vegetable oils. Other types of oils that are currently being investigated are peanut seed oil (Davis et al., 2009; Kaya et al., 2009), melon seed oils (Mabaleha et al., 2007) and safflower oil (Rashid and Anwar, 2008), Apart from these, other edible vegetable oils like canola, linseed and corn have also been used for biodiesel production and are found to be good as a diesel substitute (Freedman et al., 1986; Lang et al., 2001).

A few studies have also showed that algae could also be a possible raw material for biodiesel production (Nagel and Lemke, 1990; Chisti, 2007). Algae, in the presence of sunlight, convert carbon dioxide into sugars and protein, but when they are starved of nitrogen, they mainly produce oil. Microalgae are reported to give a higher photosynthetic efficiency, higher biomass production and faster growth as compared to other energy crops (Milne et al., 1990; Ginzburg, 1993; Dote et al., 1994; Minowa et al., 1995). However, despite tremendous interest in algae feedstocks for biodiesel production, there were only a few studies conducted in this area. Many researchers were unable to compare the algal-based feedstock to vegetable-based feedstock due to the lack of compositional profiles of the triglycerides fractions in algal lipids. The fatty acids composition of each algae strain is unique as it is highly influenced by the specific growth conditions such as nutrient levels, temperature and light intensities (Hu et al., 2008). Although there were a number of studies conducted to determine the fatty acid composition of algal lipid, the exact species is often unknown, or a mixed species is used (Hoekman et al., 2012). Base catalysed transesterification is the most adoptable technology for biodiesel production. The reaction mechanism for the transesterification process is formulated in three sequential steps, is shown in Figure 1.0.

The first step is the reaction between the base catalyst with the alcohol, forming the alkolide and the protonated catalyst. The carboxyl group of the triglycerides has a slight positive charge whereas the carbonyl oxygen of the alcohol has a slight negative charge. In the second step, nucleophilic attack takes place when the $\mathrm{C}=0$ bond of the triglycerides molecules is attacked by the anion of the alcohol, RO-, forming the tetrahedral intermediate. This intermediate has a slight negative charge which eventually falls back to the carbon bond, forming Fatty Acid Alkyl Ester, commercially known as biodiesel and the anion of diglycerides. The regeneration of active species takes places by the deprotonation of the catalyst using the latter species (anion of diglycerides). Diglycerides and monoglycerides were converted by the same mechanism as triglycerides. At the end of the process, three moles of FAAE and one mole of glycerine were formed.

Most of the biodiesel production plants nowadays use homogeneous base catalysts because they are very effective and soluble in alcohol. A homogeneous base catalyst was also preferred over a homogeneous acid catalyst because it gave a higher reaction rate, was less corrosive and required a shorter reaction time (Meher et al., 2006 a). However, these homogeneous catalysts i.e. homogeneous base and acid catalysts have some drawbacks. Biodiesel produced from a homogeneous catalysed reaction must be neutralised with water and thus this contributes to the generation of wastewater. The homogeneous catalyst cannot be reutilised, and furthermore, with the presence of a high FFA content and water, it will initiate the hydrolysis and saponification process, which leads to difficulty in the separation process. The conventional homogeneous catalyst is recommended to be replaced by environmentally friendly heterogeneous catalyst as this type of catalyst is proven to simplify the production and purification processes, reduced the amount of wastewater and cut off the number of process equipment. Therefore, the mentioned benefits will lead to a reduction in the biodiesel production cost. These catalysts were also easily separated from the reaction mixture, thus allowing multiple usage of the catalyst through a regeneration process and simultaneously this creates an environmentally friendly condition. Detailed investigation of different types of base heterogeneous catalysts such as rare earth oxides, various base metal compounds supported on alumina or zeolite, hydroxides, alkoxides, hydrotalcites and ion exchange resin have been carried out by several researchers (Watkins et al., 2004; Kim et al., 2004; Reddy et al., 2006; Granados et al., 2007; Reddy et al., 2007; ShibasakiKitakawa et al).

\section{Discussion Analysis}

From the perspective of Arabic lexicography and the code interpretation of Quran, the word (الثََََرِ الَْخَخْضَرِ) means green trees, while the word (نَار) means fuel or energy source. Green trees here means the trees are still fresh, wet and producing green fuel as a fuel or energy source. Normally, trees are used as fuel trees that are dead, dry and was discolored. If these trees are burnt, it will produce a flame that can also serve as a source of energy for humans. The green trees which can produce fire is an unusual and strange situations in human life. This is because it is relatively difficult for the green trees to produce fuel as fuel or energy source to humans. The discussion focusing on the interpretation of this verse is to how the trees of green and wet (الثنَجَرِ الْأَخْضَرِ) is able to become fuel for producing energy. This is because of the water is cold and wet, while the nature of the fire is hot and dry. These two properties are conflicting with each other. 
There are a number of interpretative understanding of the verse (الثنَّجَرِ الَْأَضْنَر). Each of these interpretations have their own arguments. This verse is a manifestation of Allah invites man to ponder and explore the branches of the new knowledge. The first opinion states that this verse is the verse of metaphor or antonomasia in the holy Quran, which leads to another meaning. This group is using the argument in the rhetorical term as a solution to this discussion. Even so, the view is still debated by some scholars of the Arab-Muslim by stating that this verse clearly shows the apparent purpose of the word (الثََُجَرِ الْأَخْضَرِ) which refers to the purpose of the green trees that produce heat. So it is not accurate if the interpretation of this verse refers to the purpose of the Arabic rhetoric view point.

Al-Baidawiy (1998:16:199) discuss this description by stating in surah Yaseen indeed there are three miracles shown by Allah to mankind. Such things are the power of Allah to revive the man from the bones that have been destroyed and become dust as found in verse 79, almighty Allah with His power produce fire from green trees as found in verse 80 and Allah the almighty who created the seven-layered sky with planets in the universe, created seven layers of earth which are inhabited by various creatures as found in verse 81 . All these three sentences are sentences that are interrelated and clearly defined in terms of the purpose of the word. It does not require the interpretation of Arabic rhetoric term. If one verse is interpreted by arabic rethoric term and accordingly the two other verses also be interpreted as such.

The problems that arise here are caused by this sentence statement contrary to human logic. Second opinion is to take alternative of the interpretation that the meaning of sentence (الثَََّرِ الَْخْضَرِ refers to the name of al-Markh trees and tree al-'Afar that grows in the Hijaz area. However, this opinion is rejected by a scientist from Saudi Arabia named 'Abdullah

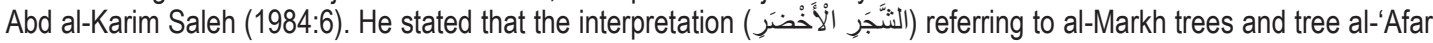
is not accurate. This interpretation is in the general state. Based on the studies that have been done by him, he found that both of these trees cannot produce a flame when they are rubbed together as claimed. Thus, the interpretation of this sentence should be carried out in more detail in order to give the reader of holy Qur'an a concise explanation.

The interpretation of production of charcoal from the wet and green trees and the discovery of petroleum as a fuel source to humans is right or merely to this discussion ('Abd al-Mun'im Fahim al-Hadiy:1996:114). Nevertheless, not all charcoal is produced from the trees are still green and wet. There is also produced from dead and dry wood. Similarly, the with the petroleum production process. It also does not just focus on the decomposition of green plants, but also involves the decay of other elements such as animals. Thus, the interpretation of this verse refers to the production of charcoal and oil is still being debated by Muslim scholars.

The findings in the field of biodiesel are currently among other interpretation closer to understanding of this verse and can also be relied on as the interpretation of this verse. Through experiments that were carried out, clearly shows that green plants are wet able to produce biodiesel used as fuel to produce energy for human use. Nevertheless, only certain plants can be used as fuel to produce this energy source.

\section{Conclusion}

(a) The holy Quran is the revelation of Allah which is packed with various branches of knowledge and its content is a miracle of Allah that should be explored by humans, especially Muslims.

(b) Interpretations of the verses of holy Quran at times depending on the progress of human knowledge. Some of the verse is interpreted with different understanding based on different time to time. Development in interpretation of these verses is actually not affecting the faith in almighty Allah, but indirectly it is an honor to the contents of holy Quran.

(c) Interpretation rhetoric of verse 80 of surah Yaseen is more likely to the field of rhetoric term in language style of holy Quran. Interpretation of this form is to obtain consistency of messages contained in the Quran the human mind.

(d) The second opinion holds that the green trees are burned to produce energy are referring to the al-Markh al and al-'Afar trees. Both of these trees are of plants that are capable of producing a fire in wet conditions by using certain techniques.

(e) Discovery of charcoal produced from trees that are still wet to be used as fuel to provide energy to the human resources also is one interpretation that is close to this text. In addition, the discovery of petroleum that supplies human resources is also contributed to the development of the interpretation of this verse. With the progress in science and technology, it can help give another interpretation which is close to the interpretation of this verse.

(f) Islamic scientists have proven with new discoveries in science and technology as a sub-interpretation of the verses of holy Quran. The findings in the field of biodiesel can be used as a backup that there were times when certain verses of the 
Quran the concept defies logic of people should not be interpreted using rhetoric term knowledge in the field of language. Instead of scientific studies should be done to prove that the scientific facts contained in the holy Quran are true.

(g) Nothing is impossible for almighty Allah, as Allah's absolute power to make something on His will although contrary to human logic. Human task is to explore the areas of new knowledge and in increase the faith towards Allah.

\section{References}

'Abdullah 'Abd al-Karim Saleh (1984). Al-Syajar al-Akhdar wa Nar al-Hayat. Majallat al-'l'jaz al-'Ilmiy. Online. http://www.eajaz.org/index.php/component/content/category/64-1.

'Abd al-Mun'im Fahim al-Hadiy (1998). 'Alim al-Nabat Fi Al-Qur'an Al-Karim. Kaherah: Dar al-Fikr al-'Arabiy.

Abu Hilal al-Hasan al-'Askariy (1988). (e.d) Ahmad 'Abd al-Salam. Kitab Jamharat al-Amthal. Beirut: Dar al-Kutub al'Ilmiyyat.

Al-Baidawiy, Nasir al-Din Abu al-Khair 'Abdullah al-Syiraziy (1998). Anwar al-Tanzil Wa Asrar al-Ta'wil. Beirut: Dar I'hya' al-Turath al-'Arabiy.

Al-Kumait bin Zaid al-Asadiy (2000). (e.d) Muhammad Nabil Tarifiy. Diwan al-Kumait bin Zaid al-Asadiy. Beirut: Dar Sadir. Al-Maraghiy, Ahmad Mustafa (1946). Tafsir al-Maraghiy. Mesir: Maktabat Mustafa al-Banniy.

Al-Qurtubiy, Abu 'Abdullah Muhammad bin Ahmad (2006). (e.d) 'Abdullah bin 'Abd al-Muhsin al-Turkiy. Al-Jami' Li Ahkam Al-Qur'an. Beirut: Muassasat al-Risalat.

Badr al-Din al-Zarkasyiy. (1984). al-Burhan Fi ‘Ulum Al-Qur'an. Kaherah: Dar al-Turath.

Balat, M. (2011). Potential alternatives to edible oils for biodiesel production-A review of current work. Energy Conversion \& Management, vol. 52, no. 2, pp. 1479-1492.

Chisti,Y. (2007). Biodiesel from microalgae. Biotechnology Advances, vol.25, no.3, pp.294-306.

Demirbas, A. (2006). Biodiesel production via non-catalytic SCF method and biodiesel fuel characteristics. Energy Conversion \& Management, vol. 47, no. 15-16, pp. 2271-2282.

Dote, Y., Sawayama, S., Inoue, S., Minowa, T. \& Yokoyama, S. (1994). Recovery of liquid fuel from hydrocarbon-rich microalgae by thermochemical liquefaction. Fuel, vol. 73, no. 12, pp. 1855-1857.

Freedman, B., Butterfield, R. \& Pryde, E. H. (1986). Transesterification kinetics of soybean oil. Journal of the American Oil Chemists' Society, vol. 63, no. 10, pp. 1375-1380.

Ghadge, S. V. \& Raheman, H. (2005). Biodiesel production from mahua (Madhuca indica) oil having high free fatty acids. Biomass \& Bioenergy, vol. 28, no. 6, pp. 601-605.

Ginzburg, B. Z. (1993). Liquid fuel (oil) from halophilic algae: A renewable source of non-polluting energy. Renewable Energy, vol. 3, no. 2-3, pp. 249-252.

Hoekman, S. K., Broch, A., Robbins, C., Ceniceros, E. \& Natarajan, M. (2012). Review of biodiesel composition, properties, and specifications. Renewable \& Sustainable Energy Reviews, vol. 16, no. 1, pp. 143-169.

Hu, Q., Sommerfeld, M., Jarvis, E., Ghirardi, M., Posewitz, M., Seibert, M. \& Darzins, A. (2008). Microalgal triacylglycerols as feedstocks for biofuel production: perspectives and advances. The Plant Journal, vol. 54, no. 4, pp. 621-639.

Ibn 'Asyur, Muhammad Tahir (1984). Tafsir al-Tahrir Wa al-Tanwir. Tunisia: Dar al-Tunisiyyat Li al-Nasyar.

Ibn 'Atiyyat, Muhammad al-Andalusiy. (2007). Al-Muharrar al-Wajiz. Beirut: Dar al-Khair.

Ibn Hayyan al-Andalusiy, Muhammad bin Yusof (1993). (e.d) 'Adil Ahmad 'Abd al-Maujud. Tafsir al-Bahr al-Muhit. Beirut: Dar al-Kutub al-'Ilmiyyat.

Ibn Kathir, Abu al-Fida' Isma'il al-Quraisiy(1999). (e.d) Samiy bin Muhammad al-Salamat. Tafsir Al-Qur'an al-'Azim. AlRiyad: Dar Taibat Li al-Nasyar wa al-Tauzi'.

Ibn Manzur, Jamal al-Din Abu al-Fasl Muhammad (1996). Lisan al-'Arab. Beirut: Dar l'hya' al-Turath al-'Arabiy.

Kim, H., Kang, B., Kim, M., Park, Y.M., Kim, D., Lee, J. \& Lee, K. 2004, "Transesterification of vegetable oil to biodiesel using heterogeneous base catalyst", Catalysis Today, vol. 93, no. 5, pp. 315-320. 
Lang, X., Dalai, A. K., Bakhshi, N. N., Reaney, M. J. \& Hertz, P. B. (2001). Preparation and characterization of bio-diesels from various bio-oils. Bioresource Technology, vol. 80, no. 1, pp. 53-62.

Lotero, E., Liu, Y. J., Lopez, D. E., Suwannakaran, K., Bruce, D. A. and Goodwin, J.G. (2005). Synthesis of biodiesel via acid catalysis. Industrial \& Engineering Chemistry Research, vol. 44, no. 14, pp. 5353-5363.

Meher, L. C., Vidya Sagar, D. \& Naik, S. N. 2006a, "Technical aspects of biodiesel production by transesterification-a review", Renewable \& Sustainable Energy Reviews, vol. 10, no. 3, pp. 248-268.

Milne, T. A., Evans, R. J. \& Nagle, N. (1990). Catalytic conversion of microalgae and vegetable oils to premium gasoline, with shape-selective zeolites. Biomass, vol. 21, no. 3, pp. 219-232.

Minowa, T., Yokoyama, S. Y., Kishimoto, M. \& Okakurat, T. (1995). Oil production from algal cells of Dunaliella Tertiolecta by direct thermochemical liquefaction. Fuel, vol. 74, no. 12, pp. 1735-1738.

Nagel, N. \& Lemke, P. (1990). Production of methyl fuel from microalgae. Applied Biochemical Biotechnology, vol. 24, no. 5, pp. 355-361.

Reddy, C. R. V., Oshel, R. \& Verkade, J. G. 2006, "Room temperature conversion of soybean-oil and poultry fat to biodiesel catalyzed by nanocrystalline calcium oxides", Energy \& Fuels, vol. 20, no. 3, pp. 1310-1314.

Reddy, C. R. V., Fetterly, B. M. \& Verkade, J. G. 2007, "Polymer-supported a zidoproazaphosphatrane: a recyclable catalyst for the room-temperature transformation of triglycerides to biodiesel", Energy \& Fuels, vol. 21, no. 4, pp. 2466-2472.

Sarin, R., Sharma, M., Sinharay, S. \& Malhotra, R. K. (2007). Jatropha-palm biodiesel blends: an optimum mix for Asia. Fuel, vol. 86, no.10-11, pp. 1365-1371.

Sharma, Y., Singh, B. \& Upadhyay, S. 2008, "Advancements in development and characterization of biodiesel: A review", Fuel, vol. 87, no. 12, pp. 2355-2373.

Shay, E. G. (1993). Diesel fuel from vegetable oil; Status and opportunities. Biomass Energy, vol.4, no.4, pp. 227-242.

Shibasaki-Kitakawa, N., Honda, H., Kuribayashi, H., Toda, T., Fukumura, T. \& Yonemoto, T. (2007). Biodiesel production using anionic ion-exchange resin as heterogeneous catalyst. Bioresource Technology, vol. 98, no. 2, pp. 416-421.

Watkins, S. R., Lee, F. A. \& Wilson, K. 2004, "Li-CaO catalyzed tri-glyceride transesterification for biodiesel applications", Green Chemistry, vol. 6, no. 7, pp. 335-340.

Zamri Rajab, Kaseh Abu Bakar. (2011). Penggunaan Shahid al-Qur'ān Dalam Kitab Sharh Ibnu cAqīl Dan Sharh Qatr AlNadā Wa Bal Al-Sadā Bab al-Marfucāt: Satu Kajian Bandingan. GEMA Online ${ }^{\mathrm{TM}}$ Journal of Language Studies 11(2), 8398. 